\title{
Gender Politics in the Projection of "Disney” Villains
}

\author{
Tania Sharmin, Sanyat Sattar \\ Jahangirnagar University, Dhaka, Bangladesh
}

\begin{abstract}
Disney being one of the most influential media giants in the world, attracting both young and adults equally and creating memorable characters for almost 80 years, has introduced some memorable villain characters. But interestingly, the projection of male and female villains is rather different and often questionable. This paper aims to investigate how the evil characters have an unequal projection in terms of their gender roles.
\end{abstract}

Keywords: villain, gender, animation, masculinity, gender-bending

\section{Introduction}

Most of the heroes and heroines of the Disney franchise films fell in love, get married to live happily ever after. They reveal stereotypical and exaggerated portrayals of a traditionally gendered appearance that attracts an equally stereotypical character of the other sex. The female villains of Disney films, however, offer a distinct pattern through appearance and behavior, which is quite different from the hyper-heterosexual heroes and heroines, and also from their male counterparts. Obviously the villains need to be different and creepy to differentiate themselves from the protagonists, but when it comes to female villains (i.e. villainess) the projection is rather problematic.

\section{Appearance Matters}

A proliferation of stereotypically female behaviors, pre-occupations with domestic work, as well as an affinity for animals is a typical feature for most of the princess characters in Disney animations, who are portrayed as "ultra-feminine." Characters like Aurora, Cinderella, Belle, Tiana, Rapunzel, Snow White are expert in singing and dancing, and are seemingly enjoying their household chores. These traditional female behaviors are used as standardized portrayal of femininity and beauty.

Disney heroes play a smaller part than their princess; however, they do embody normative characteristics in their appearance and behavior. Taller than each respective princess, broad-shouldered, square-jawed, and muscular, their attributes become standardized heterosexual male physical characteristics. They also participate in "manly" activities, such as horseback riding, hunting, sailing, sword-fighting, and even hand-to-hand combat, when necessary.

Dramatic and daring, the villains often outperform their rivals, setting up a transparent comparison between "normative” and "deviant” gendered behaviors, with sarcasm, selfishness, cruelty, greed, and brutality.

Tania Sharmin, Assistant Professor, Department of English, Jahangirnagar University.

Sanyat Sattar, Ph.D., Professor, Department of English, Jahangirnagar University. 
According to Ollie Johnston, and Frank Thomas 55\% of Disney film villains are either women or "feminized men” and among them 25\% are emaciated. Three out of the four of them are in fact old, ugly and unattractive. This is also substantiated by the movie plots where the female villains almost never appear desirable or beautiful in the eyes of the opposite sex. This associates villainy in females with unattractiveness and undesirability especially, comparing to the slenderness, fairness, and youth of female heroines who are almost essentially portrayed as the epitomes of beauty.

Male villains are also mostly portrayed obese and burly. But large men unlike large women are not necessarily unattractive as per the visual concept of beauty. If we consider Disney animation into account it can be seen that several male villainous characters such as Gaston from The Beauty and the Beast and Governor Ratcliff from Pocahontas are not ugly looking men. On the contrary they project similar vigour and handsomeness that the male protagonists do in the individual films. Male villains also tend to have various stylized features such as facial hair (Captain Hook), pointed teeth (Hades) or hawk-like eyes (Shan-yu), long hair with blue eyes (Gaston).

Prince Hans Westergaard of the Southern Isles is the main antagonist of Disney's 53rd full length animated feature film, Frozen. Appearance wise, this character is outstandingly handsome, and for some extend more handsome and dashing than the hero of the story. This also shows how the male villains are being projected in this recent Disney project.

The ideas that many Disney films portray regarding appearance is generally that set by the hegemonic standards of beauty, which is not the case with the female villains. On the other hand, a villainous appearance does not have such paramount in determining the desirability of a male. Most female villains are generally designed to look unattractive. For many female villains, highly identifiable features that usually denote femininity are hidden, designed to be misshapen, or are made to look grossly terrible. Ursula, the Sea Witch in The Little Mermaid, is a huge black and purple octopus, with styled white hair standing straight up, large eyes with deeply painted lids of blue and gray, and incredibly arched eyebrows. Her huge lips and nails are painted bright red, and she has a "beauty mark" mole on her right cheek. Her makeup, saggy jowls and large breasts create a vaguely female, voluptuous figure; however the exaggeration of those features, combined with her deep voice and overtly sexualized body movements suggests something much more masculinized. The Disney Villain remarks that "when we first see her in the film, we are appalled at her appearance, and realize that here is someone to be reckoned with."

Ursula's queerness subverts gender categories thus turning this female witch into "a multiple cross-dresser," who destabilises gender through her excess and theatricality. When Ursula suggestively tells Ariel to use "body language” to attract Prince Eric, Ursula’s overweight body and tentacles, her deep voice, and the excessive, sexualized shimmies are reminiscent of a drag queen on stage.

The one method Disney employs to render a female character unattractive is by de-feminizing her. While Yzma and Madame Medusa have misshapen breasts, The Tremaine stepsisters from Cinderella are shown to be largely flat-chested, a contrast to the beautiful Cinderella whom they are jealous of. Sometimes, other common associations with beauty and femininity are often removed from female villains. 


\section{Triviality in Action}

In many of the cases some female characters are portrayed to "turn into" villains for very trivial matters. The evil queen in Snow White and the Seven Dwarfs is shown to be evil for her beauty; that is because she wants herself to be the "fairest of all." Lady Tremaine in Cinderella is shown to be rude and cruel to her stepdaughter. Tremaine's disdain for her kind-hearted stepdaughter leads her to sabotage Cinderella's ongoing efforts at getting close to prince charming. And the only reason is because Cinderella is pretty, beautiful and likable by all. In Tangled, an adaptation of Rapunzel, we see Mother Gothel to be stealing baby Rapunzel and hide her in a tower only to keep Mother Gothel young and beautiful. In 101 Dalmatians, the villain is Cruella De Ville, the middle-aged villain, wants to kill the puppies in order to design a dog-skin fur coat. Cruella, who is truly cruel and materialistic, is less attractive, less intelligent and more aggressive.

There are many familiar characters in the long line of Disney animations such as the evil queen, Ursula, Cruella De Ville, Madame Medusa, Lady Tremaine, The Queen of Hearts, Yzma, and many more. Yet, there is rather less variety in the projection of any of these characters. All of them are suffering from almost similar predicaments. Which is not quite the case in terms many of the evil male villains such as Gaston, Hades, Captain Hook, Dr. Facilier, and Professor Ratigan and so on.

According to the survey conducted by Debra Bradley, it is found that as for the female villains, the top motive is jealousy/vanity (28\%) and inherent evil (27\%). This is very different from motives of male villains as only $4 \%$ are driven by jealousy/vanity and interestingly only $8 \%$ are driven by inherent evil. On the contrary most of the male villains are driven by wealth (38\%) and power (33\%), which may refer to status symbols often associated with patriarchal masculinity.

\section{Masculinized Women and Feminized Men}

Many of the female Disney villains are subtly masculine - their faces, body shape, and behavior lend "mannish" traits to their characters. In portraying them this way, the villains contrast sharply with the ultra-feminine princesses.

The transgression of gender roles occurs in many Disney films, most notably in the Princess series, but also in animal-themed films as well. Specifically, several villainous female characters are masculinized in distinct ways, for example the stepmother and stepsisters in the Cinderella series and Ursula in The Little Mermaid. However, the gender-bending traits appear within male villains as well, as they are given feminine traits_some bordering on an implicit homosexual characterization. Specifically, The Lion King's Scar, Aladdin's Jafar, become womenized villains. When transgendered qualities are marked as only apparent in evil characters, then a stigmatized standard of normative behavior is being created and promoted. Meredith Li-Vollmer and Mark E. LaPointe (2003) indicate in their article "Gender Transgression and Villainy in Animated Film," that "Gender is established and sustained by socially required identificatory displays; through interaction, gender is continually exhibited or portrayed, and thus comes to be seen as 'natural'” (p. 190). Whether the case is with masculinized women or womanized men, ultimately it undermines the women.

\section{Female Villains and Their Audience}

Children, 8-13 years of age, who view television cartoons in a study by Bell and Haas recognize that the 
cartoon characters exhibit stereotypical gender role behaviors. They also find that males outnumber females on Saturday morning cartoons. More important than their numbers, though is the fact that male characters are portrayed in a much greater variety of roles and occupations. Female characters are seen as housewife-mother, girlfriend, grandmother, aunt villain's daughter, maid, nanny, nurse, secretary, waitress, TV reporter, and circus-performer, cheer girls and witch (mostly). They conclude, "Television portrayal of the sexes in cartoons did not reflect real world values concerning traditional gender-role assumptions.” (p. 20)

\section{Maleficent VS Maleficent}

"Sleeping Beauty" is a classic fairy tale written by Charles Perrault and the Brothers Grimm, which involves a beautiful princess, a sleeping enchantment, and a handsome prince. The 1959 animated version of the story portrays the villain Maleficent, as an obviously wicked character. It has been said that Maleficent is Disney's most evil villain of all times. The untold past, present or future of this character, or having no "serious" logical explanation for her cursing the princess makes Maleficent more complex as a character. Maleficent transforms into a dragon to finally kill the prince charming is to save the princess with his kiss. Like the recent phenomenon in Disney franchising their old animated films into live action cinema, the 2014 version of Maleficent portrays quite a different perspective of the said character. Here the famous villain has a story to tell and does not simply appear from nowhere and start cursing. It is shown that the character Maleficent became evil for a specific reason - a horrible betrayal. She is shown to have a softer side of the heart when she cries over the loss of her wings. She even feels sorry for Princess Aurora whom she cursed with a spell and later even wants to free Aurora from it. This is because Maleficent knows that the criminal is King Stephan who betrayed her and took away her wings. She realizes that the princess is innocent, but tolerates the wrath of Maleficent due to her (Princess) father. Even, at last Aurora's spell is broken by the sincere love of Maleficent for her, but not by the true kiss of the prince. The audience feels sorry for this Maleficent, instead of hating her.

As discussed earlier Disney female villains are projected either ridiculous or ugly. However, the 2014 version of Maleficent is rather attractive, even though she carries horns and giant wings. This indeed is a big leap as far as the projection of Disney villains are in concern.

\section{Conclusion}

In these ways, female villains become more and more separated from their dainty heroines, and their carefully-crafted creepiness depends on a distinct division from traditionally feminized characteristics. It is understandable that the villains would appear distinctly different, but the repeated portrayal of the women as hideous villains concerned with triviality does make the whole idea questionable.

Disney films are often regarded as harmless family entertainment-one in which members of all ages are welcome to enjoy. As such, the female villains and their male counterparts offer an interesting contrast to each other that conveys a problematic message about gender and difference that is being sent consistently conveyed to Disney’s child viewers.

\section{References}

Ashliman, D. L. (2009). “Cinderella.” Grimm Brothers' Home Page. Original by Jacob and Wilhelm Grimm, 1857. http://www.pitt.edu/ dash/grimm021.html. 
Bell, E., Haas, L., \& Sells, L. (1995). Introduction: Walt's in the movies. From mouse to mermaid: The politics of film, gender, and culture (pp. 1-20). Bloomington: Indiana University Press.

Bradley, D. (1995). Disney gives pocahontas sexiest cartoon image ever. Dallas Morn-ing News, The Free-Lance Star, June 23, Retrieved from http://news.google.com/newspapers?nid=1 298\&dat=19950623\&id=uy0zAAAAIBAJ\&sjid=wQcGAAAAIBAJ\&pg=3630,4507147

Disney Villains. (2010). Retrieved from http://www.disneyvillains.net/

England, D., \& Descartes, L. (2008). Gender role portrayal and the Disney Princesses. University of Connecticut. April 19,. Honors Thesis Poster Pres- entation. 12 January 2010. http://www.familystudies.uconn.edu/undergraduate/honors /posters/Dawn\%20England\%20poster.pdf

Hill, J. (2007). Jim Hill Media, “Why (For) Pat Carroll Wasn’t Actually Disney’s First Choice to Voice Ursula in 'The Little Mermaid.”, Retrieved from http://jimhillmedia. com/blogs/jim_hill/archive/2007/06/15/why-for-pat-carroll-wasn-t-actually-disney-s-first-choice-to-voice-ursula-in-the-little -mermaid.aspx

Jacobs, I. S., \& Bean, C. P. (1963). Fine particles, thin films and exchange anisotropy. In G. T. Rado and H. Suhl (Eds.), Magnetism (Vol. III) (pp. 271-350). New York: Academic..

Johnston, O., \& Thomas, F. (1993). The Disney Villain. Hyperion: New York.

Li-Vollmer, M., \& LaPointe, M. E. (2003). Gender transgression and villainy in animated film. Popular Communication, 1(2), 89-109.

Lowrey, S. (2007). "I'll Glitter." Fuchsia Focus: A Queer Critique of the Media. Retrieved from http://fuchsiafocus.blogspot.com/2007/07/ill-glitter.html

PFLAG: Parents, Families, and Friends of Lesbians and Gays. “About Our Transgendered Children.” Out of the Closet Into Our Hearts. February 25, 2007. Retrieved from http://www.criticspflag.com

RAINN: Rape, Abuse, and Incest National Network. “Statistics.” 2009. http://www. rainn.org/statistics

Tanner, L. R., et al. (2003). Images of couples and families in Disney feature-length animated films. American Journal of Family Therapy, 31(5), 355. Academic Search Premier. EBSCO.

Towbin, M. A., et al. (2003). Images of gender, race, age, and sexual orientation in Disney feature-length animated films. Journal of Feminist Family Therapy, 15(4), 19-44. Academic Search Premier. EBSCO.

Voicing 'Scar' in The Lion King_Jeremy Irons. June 05, 2009. http://www.youtube.com/ watch?v=apJxdRYI32Y

Willman, C. (1994). You can’t hide his lion eyes. Originally in Los Angeles Times. Reprinted in Irons Ink: Press Archive. 15 May 1994. http://www.jeremy-irons.com /press/archive/18.html

Yorozu, Y., Hirano, M., Oka, K., \& Tagawa, Y. (1987). Electron spectroscopy studies on magneto-optical media and plastic substrate interface (J. Magn. Trans.). IEEE, 2, 740-741. 